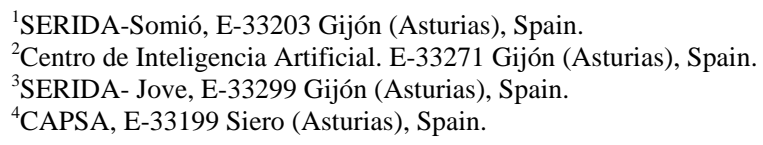

FÉLIX GOYACHE ${ }^{1}$, JORGE DÍEZ ${ }^{1,2}$, SECUNDINO LÓPEZ ${ }^{2}$, GERARDO PAJARES ${ }^{1}$, BEGOÑA SANTOS ${ }^{4}$, IVÁN FERNÁNDEZ ${ }^{1}$, and MIGUEL PRIETO ${ }^{3}$

\title{
Machine Learning as an aid to management decisions on high somatic cell counts in dairy farms
}

\begin{abstract}
High somatic cell counts (SCC) is associated with mastitis infection, in dairy herds, worldwide. This work describes Machine Learning (ML) techniques designed to improve the information offered to farmers on animals producing high SCCs according to particular herd profiles. The analysed population included 71 dairy farms in Asturias (Northern Spain) and a total of 2,407 lactating cows. Four sources of information were available: a) a questionnaire survey describing facilities, milking routines and management practices of the farms studied; b) dairy recording information; c) classification of the cows suspected of being healthy or subclinical mastitic according to farmers' expertise; and d) positive or negative scores with respect to the California Mastitis Test (CMT). The decimal logarithm of the SCC (linear score), lactation number, herd size, lactating cows per milker, milk urea concentration, number of clusters per milker and actual SCC are shown to be the most informative attributes for mimicking both farmers' expertise or CMT performance in order to identify animals producing persistently high SCCs in dairy herds. However, to improve the identification of cows suspected of being non-healthy, the system uses other information related to management and milking routines. Decision rules to predict CMT performance can provide useful, additional information to farmers to improve the management of dairy herds included in milk recording programs.
\end{abstract}

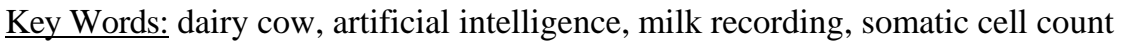

\section{Zusammenfassung}

Titel der Arbeit: Künstliche Intelligenz (AI) als Hilfe für betriebliche Entscheidungen bei hohem somatischen Zellanteil (SCC) in Milchviehhaltungsbetrieben

Hoher somatischer Zellanteil (SCC = somatic cell count) wird in der Milchviehhaltung weltweit mit dem Auftreten von Brustdrüsenentzündungen in Verbindung gebracht. In dieser Arbeit werden Techniken künstlicher Intelligenz vorgestellt, die zur Verbesserung der Information der Landwirte über Milchkühe mit hohem SCC entsprechend den jeweiligen Profilen der landwirtschaftlichen Betriebe entwickelt wurden. Die untersuchte Gruppe bestand aus 71 landwirtschaftlichen Betrieben in Asturien (Nordspanien) mit einer Gesamtanzahl von 2.407 produzierenden Milchkühen. Es standen vier Informationsquellen zur Verfügung: a) ein Umfragebogen zu betrieblichen Einrichtungen, Melkabläufen und Betriebsführung der untersuchten Bauernhöfe; b) Kontrollinformation Milchproduktion; c) Klassifizierung der Kühe in gesunde oder Tiere mit Verdacht auf subklinische Mastitis entsprechend den Erfahrungswerten des Milchbauern und d) positive oder negative Befunde beim California Mastitis Test (CMT). Der Zehnerlogarithmus des SCC-Werts (linear score), Melkfrequenz, Herdengröße, Anzahl der produzierenden Kühe je Melkmaschine, Harnstoffkonzentration, Anzahl der Melkpunkte und der reale SCC-Wert erwiesen sich dabei als die aufschlußreichsten Merkmale bei der Verschmelzung der Sachkenntnis der Milchbauern mit den CMT-Ergebnissen zur Erkennung von Tieren mit anhaltend hohen SCC-Werten in Milchkuhherden. Zur besseren Erkennung von Kühen mit Verdacht auf subklinische Masitis verwendet das System weitere Informationen bezüglich Bewirtschaftung und Melkabläufen. Die Entscheidungsregeln zur Vorhersage der CMT-Ergebnisse können den Landwirten zusätzliche, nützliche Informationen zur Verbesserung der Bewirtschaftung von Milchviehhaltungen mit angeschlossenen Milchproduktionskontrollprogrammen geben.

Schlüsselwörter: Milchkuh, künstliche Intelligenz (AI), Milchkontrollprogramm, Zählung somatischer Zellen 


\section{Introduction}

Bulk milk for sale in the European Union is required to have a somatic cell count (SCC) of less than 400,000 cells/ml. Dairy market operators have introduced penalties and bonus on farmers' returns according to SCC. In these conditions the design of new tools to help farmers to limit SCC is demanded by groups specialised in producing high quality milk and becomes an important goal in dairy production (BALTAY, 2002; SKAZARD et al., 2003). The most reliable information the farmers can use to limit SCC is derived from dairy recording. However, many farmers using milk recording do not use SCC records because of the complexity of the information management (MILLER et al., 1988). Usually they pay attention to a given threshold of individual SCCs, above which they assume a cow to be mastitic and apply a relevant diagnostic technique to confirm it. However, the SCC is lacking in certain aspects that makes its interpretation difficult, such as the tremendous seasonal or age-dependent variation between SCCs with or without mastitis even with a properly carried out sampling and count (NATZKE, 1978; BALTAY, 2002). Additionally, persistently high SCCs can be found in herds where available facilities and herd management cannot be distinguished from other nearby herds showing normal SCCs (KHAITSA et al., 2000). Despite these shortcomings, the observation of SCC trends from one period to another serves to evaluate whether any progress has been made, or if the situation is stable or deteriorating. The use of decision support systems (DSS) has been proposed to realise the full management benefit of SCC records (ALLORE et al., 1995). The application of Machine Learning (ML) techniques is therefore proposed for the development of a DSS, able to manage all this information (HOGEVEEN et al., 1994). The aim of this work is to highlight the possibilities of using ML techniques to deal with this task. They can be used to ascertain the major attributes affecting process performance and obtain sound assessments, comparable to accepted human performance, when classical statistical tools are not available (GOYACHE et al., 2001).

\section{Table 1}

Mean and standard deviation of the main productive variables, at a test-day level, included in the initial training set in the full dataset and according to farm size: small $(\mathrm{N}=21)$, average $(\mathrm{N}=34)$ and large $(\mathrm{N}=16)($ Mittelwert und Standardabweichung der wesentlichen Produktivitätsvariablen am Kontrolltag, enthalten im Übungssatz, im vollständigen Datensatz und entsprechend der Größe des Bauernhofs: klein N=21), mittelgroß ( $N=34)$ und groß $(\mathrm{N}=16))$

\begin{tabular}{lcccccccc}
\hline & \multicolumn{2}{c}{ Full dataset } & \multicolumn{2}{c}{ Small farms } & \multicolumn{2}{c}{ Average farms } & \multicolumn{2}{c}{ Large farms } \\
\cline { 2 - 8 } Variable & Mean & s.d. & Mean & s.d. & Mean & s.d. & Mean & s.d. \\
\hline Average herd size & 42.3 & 15.1 & 25.3 & 2.9 & 36.0 & 5.8 & 59.7 & 9.7 \\
Individual milk yield (kg) & 27.2 & 8.8 & 25.2 & 8.2 & 26.7 & 8.3 & 29.0 & 9.2 \\
Fat percentage & 3.7 & 0.9 & 3.8 & 0.8 & 3.7 & 0.8 & 3.8 & 0.9 \\
Protein percentage & 3.2 & 0.4 & 3.1 & 0.4 & 3.2 & 0.4 & 3.2 & 0.4 \\
Milk urea concentration & 248 & 85.4 & 210 & 53.6 & 356 & 44.3 & 596 & 138.6 \\
(mg/l) & & & & & & & & \\
SCC $\left(10^{3} / \mathrm{ml}\right)$ & 265 & 594 & 234 & 536 & 270 & 595 & 275 & 623 \\
Cows per milker & 18.6 & 20.6 & 16.1 & 22.3 & 16.2 & 16.7 & 23.2 & 23.3 \\
\hline
\end{tabular}

\section{Material and methods}

\section{Data}

A questionnaire survey was carried out by clinical veterinarians on 71 dairy farms in Asturias (Northern Spain) comprising a total of 2,407 Spanish Holstein cows. Asturias is a humid and mountainous region that produces the $12.5 \%$ of the milk of Spain. Farms 
were included in the same dairy recording scheme and in a milk quality improvement program. An overall description of the main variables used in the learning process is shown in Tables 1 and 2.

Table 2

Incidence (in percentage) of variables obtained from the questionnaire survey included in the initial training set, in the full dataset and according to farm size: small $(\mathrm{N}=21)$, average $(\mathrm{N}=34)$ and large $(\mathrm{N}=16)$ (Anteil (in \%) der in der Umfrage erfassten Variablen, enthalten im Übungssatz, im vollständigen Datensatz und entsprechend der Größe des Bauernhofs: klein N=21), mittelgroß ( $N=34)$ und groß $(\mathrm{N}=16)$ )

\begin{tabular}{|c|c|c|c|c|}
\hline Variable & Full dataset & Small farms & Average farms & Large farms \\
\hline \multicolumn{5}{|l|}{ Housing system } \\
\hline loose & 47.9 & 28.6 & 50.0 & 68.8 \\
\hline tied & 52.1 & 71.4 & 50.0 & 31.2 \\
\hline \multicolumn{5}{|l|}{ Bedding system } \\
\hline sand & 4.2 & 9.5 & 2.9 & 0.0 \\
\hline sawdust & 8.5 & 9.5 & 5.9 & 12.5 \\
\hline concrete & 42.2 & 57.1 & 41.2 & 25.0 \\
\hline rubber & 35.2 & 23.9 & 44.1 & 31.3 \\
\hline straw & 9.9 & 0.0 & 5.9 & 31.2 \\
\hline \multicolumn{5}{|l|}{ Bedding sanitation } \\
\hline yes & 94.4 & 95.2 & 91.2 & 100.0 \\
\hline no & 5.6 & 4.8 & 8.8 & 0.0 \\
\hline \multicolumn{5}{|l|}{ Milking facilities } \\
\hline pipe-line system & 50.7 & 42.9 & 50.0 & 62.5 \\
\hline milking parlour & 49.3 & 57.1 & 50.0 & 37.5 \\
\hline \multicolumn{5}{|l|}{ Number of clusters } \\
\hline 3 or 4 & 57.7 & 76.2 & 58.8 & 31.3 \\
\hline from 5 to 8 & 38.0 & 13.8 & 35.4 & 62.4 \\
\hline 10 or more & 4.3 & 0.0 & 5.8 & 6.3 \\
\hline \multicolumn{5}{|l|}{ Milkers per farm } \\
\hline 1 & 23.9 & 19.1 & 29.4 & 18.8 \\
\hline 2 & 69.0 & 76.2 & 64.7 & 68.8 \\
\hline 3 & 7.1 & 4.7 & 5.9 & 12.4 \\
\hline \multicolumn{5}{|l|}{ Milking order } \\
\hline yes & 70.4 & 71.4 & 61.8 & 87.5 \\
\hline no & 29.6 & 28.6 & 38.2 & 12.5 \\
\hline \multicolumn{5}{|l|}{ Forestripping check } \\
\hline yes & 84.5 & 90.5 & 79.4 & 87.5 \\
\hline no & 15.5 & 9.5 & 20.6 & 12.5 \\
\hline \multicolumn{5}{|l|}{ Teat drying system } \\
\hline paper towel & 84.5 & 80.5 & 88.2 & 81.2 \\
\hline cloth towel & 15.5 & 19.5 & 11.8 & 18.8 \\
\hline \multicolumn{5}{|l|}{ Premilking teat sanitation } \\
\hline yes & 83.1 & 76.2 & 82.4 & 93.8 \\
\hline no & 16.9 & 23.8 & 17.6 & 6.2 \\
\hline \multicolumn{5}{|l|}{ Postmilking teat sanitation } \\
\hline yes & 95.8 & 90.5 & 100.0 & 93.7 \\
\hline no & 4.2 & 9.5 & 0.0 & 6.3 \\
\hline \multicolumn{5}{|l|}{ Dry-off system } \\
\hline abrupt cessation & 87.4 & 90.5 & 88.2 & 81.3 \\
\hline intermittent milking & 12.6 & 9.5 & 11.8 & 18.7 \\
\hline \multicolumn{5}{|l|}{ Dry cow therapy } \\
\hline general administration & 84.5 & 76.2 & 88.2 & 87.5 \\
\hline selective administration & 11.3 & 19.0 & 8.9 & 6.3 \\
\hline no dry cow therapy & 4.2 & 4.8 & 2.9 & 6.3 \\
\hline
\end{tabular}

For descriptive purposes, farms have been grouped according to their size into: small, average and large farms (less than 30, from 30 to 49, and 50 or more lactating cows, respectively). Data concerning milk yield, and fat, protein and urea contents, and SCC at 
a test-day level were obtained from dairy recording for each cow and farm included in the study (Table 1). Dairy records of every lactating cow in farm were gathered when a given cow was considered suspect or a CMT was carried out. When available, the data of the previous month's productive performance from a given cow and its herd, always at a test-day level, was included in the training set used as input for the ML procedure. Thus, a minimum of 2 and a maximum of 6 records per cow and farm were available, totalling 7,292 records. The number of records obtained from 684 cows classified as suspect in a given month was 2,293 (3.3 records per cow). To test the homogeneity of the productive and management conditions we performed Duncan's multiple range and Chi-square tests on continuous and categorical variables, respectively, using SAS® (1999). The information obtained from the survey included 13 variables describing farm facilities and the milking routine (Table 2).

Farmers were asked to classify their cows as healthy or suspected of being subclinical mastitic according to their own experience and observed changes (usually very light) in the milk (flakes, clots or serum) observed by pre-stripping cows before milking, changes in the udder (swelling, discoloration or hardness), or changes in the cow (fever, reduced appetite, diarrhoea or increased respiratory rate). Only animals with no observable clinical symptoms of mastitis were classified. A total of 684 cows $(28.4 \%$ of the available cows) were classified as suspect. The CMT was carried out on these suspect cows by trained experts. CMT results were scored as 0 (negative), 1 (trace), and 2, 3 and 4 (the higher the score, the higher the reaction). A total of 544 cows (22.6\%) were considered as CMT-positive where at least a quarter was scored as 1. CMT was carried out at least one more time on CMT positive cows. Consecutive CMTs were performed always in average intervals of four weeks.

\section{Machine Learning system}

The learning process was performed using the ML system C4.5 (QUINLAN ,1993). This algorithm produces decision trees formed by nodes with the conditions that should be accomplished generating linear functions used to predict numeric values and branches labelled with one of the classes to be learned. C4.5 uses the 'gain ratio' as the criterion for splitting nodes. The basic idea is to split the current training set in such a way that information required to classify the examples can be minimised. The program can generate trees in iterative mode starting with a randomly-selected subset of the data (the window), generating a trial decision tree, adding some misclassified objects, and continuing until the trial decision tree correctly classifies all objects not in the window or until it appears that no gain is obtained. After each tree is generated, it is pruned in an attempt to simplify it. All trees produced, both pre- and post-simplification, are evaluated on the training data. The 'best' pruned tree (selected by the program if there is more than one trial) is saved in machine-readable form.

\section{Learning process and relevancy}

A diagram describing the learning process is shown in Figure 1. The input of the learning system (in ML terms, the 'training set') included 37 attributes per farm: 13 from the questionnaire survey and 24 from dairy recording at a cow and herd levels (12 corresponding to the previous month's production performance of the cow and herd) and two possible classes: suspect/healthy and CMT-positive/negative. To feed the ML system we first found the more 'relevant' set of attributes to represent computationally the problem we would like to solve. In ML field words the more relevant attributes are those 
a)

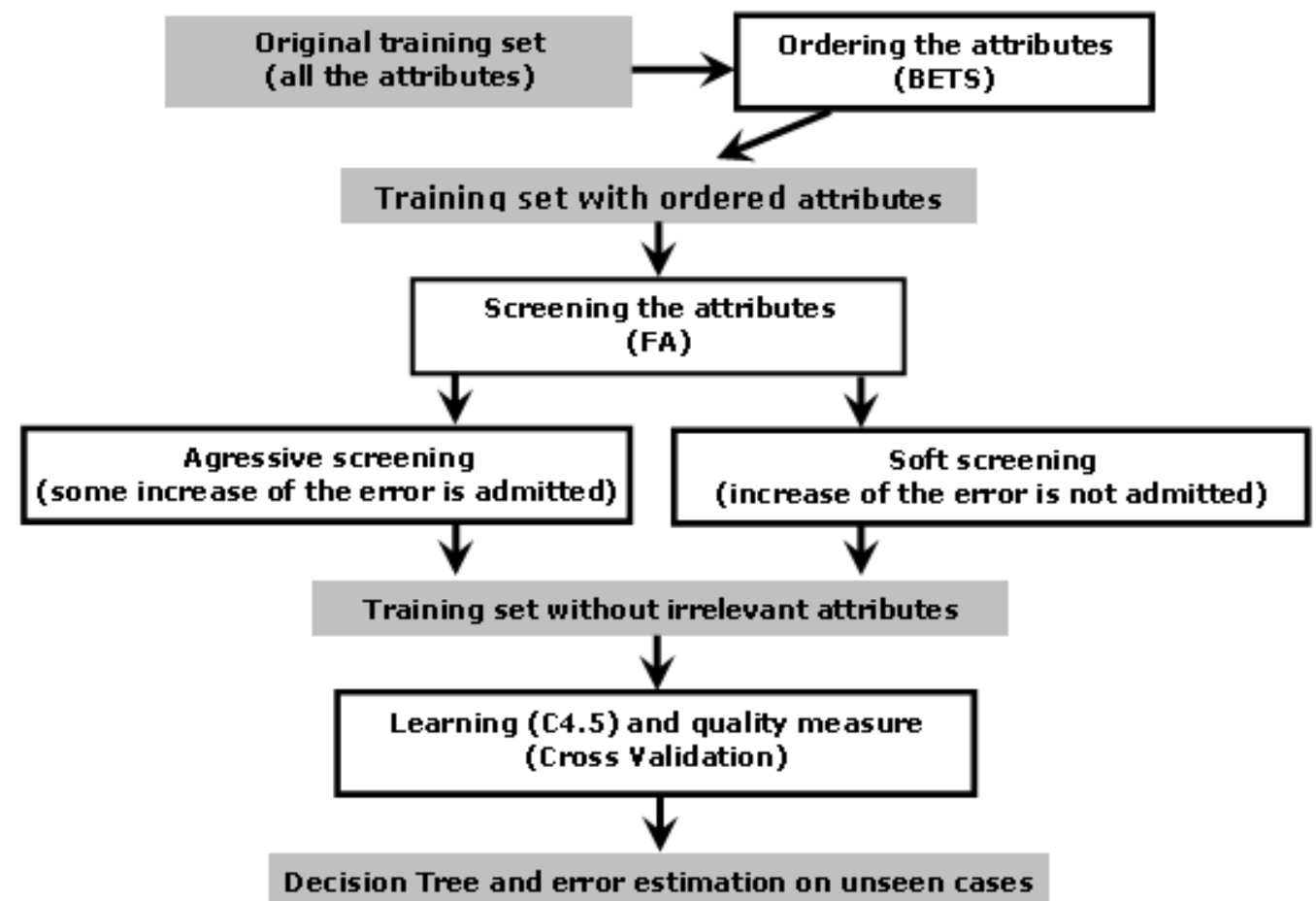

b)

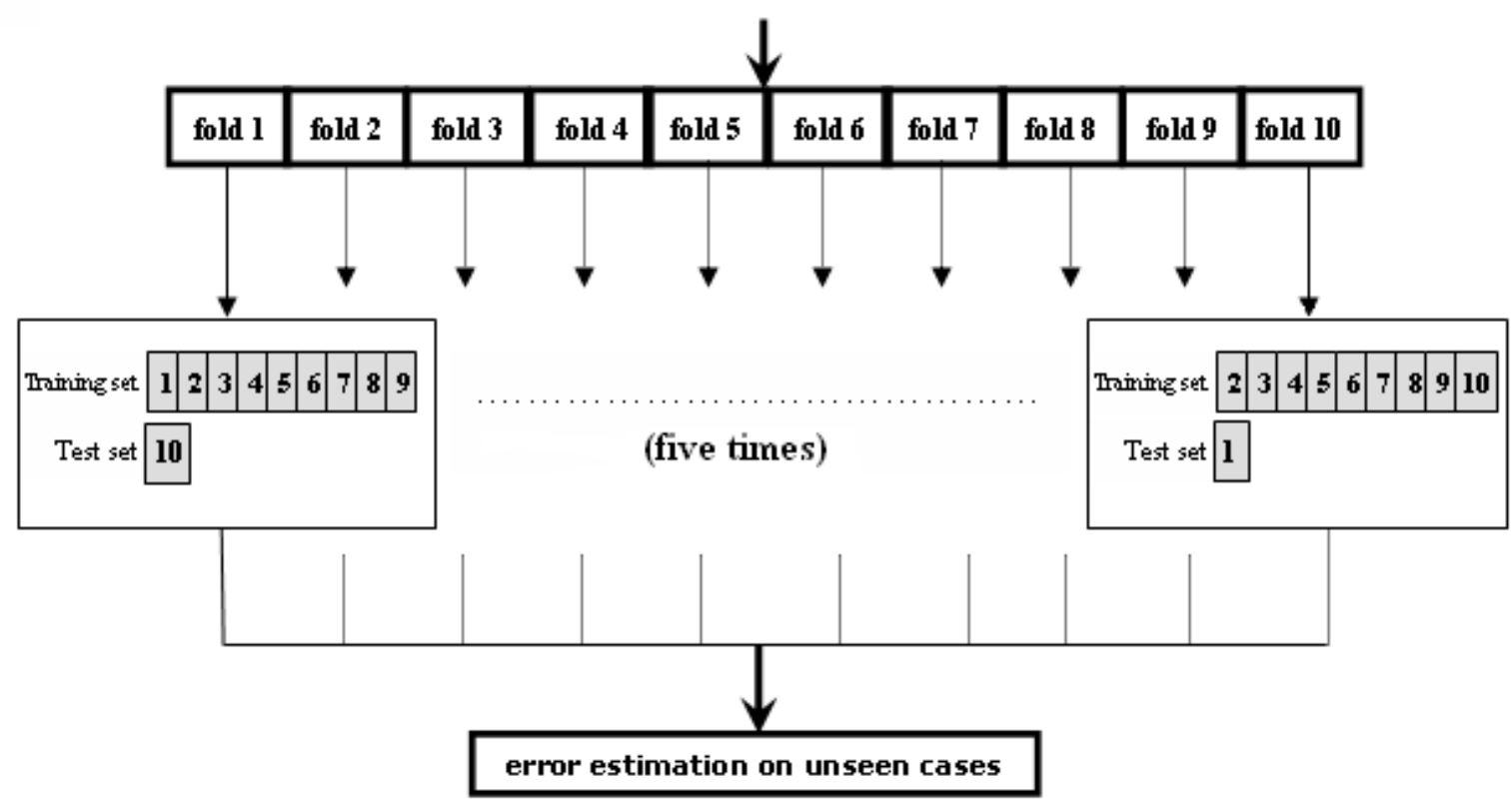

Fig. 1: Diagram describing: a) the different steps of the learning process and the screening of the attributes implemented to estimate its relevancy; and b) the cross validation methodology. Learning process uses BETS and FA to find useful training sets to be used as input of C4.5. The training sets were divided into 10 folders which were successively used as test sets (Schaubild mit a) den unterschiedlichen Schritten des Lernprozesses und der Überprüfung der eingesetzten Merkmale zur Bewertung ihrer Relevanz und b) der Cross-ValidierungMethodik. Der Lernprozess setzt BETS und FA zur Bestimmung von Übungssätzen, die als C4.5-Input einsetzbar sind, ein. Die Übungssätze wurden in 10 Ordner unterteilt, die nacheinander als Test-Sets eingesetzt wurden)

presenting the best ratio between the prediction error and the number of attributes used. To carry out this process, a combination of ML tools successfully implemented 
previously (GOYACHE et al., 2001; DÍEZ et al., 2003) was used. First we used BETS Best Examples in Training Sets- (DEL COZ et al., 1999). BETS estimates the degree to which the value of a given attribute helps to decide a given class giving an ordering of the relevancy of the attributes which is useful to differentiate between relevant and irrelevant attributes across the initial training set. Secondly we applied FA -Filtering Attributes- (QUEVEDO et al., 2001; GOYACHE et al., 2001) on the relevant attributes selected by means of BETS. FA removes the less relevant attribute and, in a subsequent step, checks the usefulness of the resulting training set to carry out the learning process. Using FA rigorous screening of the attributes was possible. If we only remove a given attribute when the resulting error of prediction is equal to less than that obtained with the training set including the attribute, we perform the called 'smooth screening'. However, if the selected training is still too complex to be easily managed, we perform a 'hard screening' accepting a small increase in the error obtained by the resultant training set after removing the less relevant attributes. In any case, FA checks the efficiency of the selected training set by means of the nearest-neighbour system where the number of neighbours to be used was calculated as a function of the number of examples.

The combination of the aforementioned tools made it possible to obtain first an ordering of the attributes taking into account their relevancy and secondly, the removal of the less relevant attributes. The obtained training sets were used as input for the C4.5 system.

The accuracy of the performance of the ML procedure was estimated by cross validation. The training sets were divided into 10 folders. Each of these folders was successively used as a test set while the other 9 were used for training. The prediction function obtained by the ML procedure from the other 9 folders was applied for each example from the test folder, and then the absolute difference with respect to the class of the example was computed. The experiment was run 5 times, finally returning the average of the differences thus computed as a faithful estimation of the accuracy of the ML procedure acting on the whole training set when the prediction functions to unseen cases were applied.

\section{Results}

Major attributes included in the training set has been described in Tables 1 and 2. These herds are representative of dairy management and production structures in the north of Spain. The average number of lactating cows per farm was 42.3 , but $30 \%$ of the studied farms had less than 30 lactating cows. Only 22\% of the farms possessed more than 50 lactating cows. The Chi square test did not show significant differences with respect to the size of the herd for the variables involved, except for the bedding system and number of clusters per milker. Productive performance was consistent across herds. Duncan's multiple range test did not show significant differences for individual milk yield, fat, protein and milk urea concentration, individual SCCs or cows per milker according to size of dairies (Table 1). In addition, there were no significant differences in the distribution of heifers and multiparous cows across dairies, even when herd size was taken into consideration.

Table 3 shows the main results of the C4.5 performance, analysing the initial training set and the resulting training sets after the application of smooth or hard screening of the initial training set using the FA tool. In addition, Figure 2 shows the decision tree generated by $\mathrm{C} 4.5$ to predict CMT performance using as input just five attributes. The differences in classification of the examples between the learning system and the initial 
training set are consistent regardless of the target class (farmers' expertise or CMT) or the number of attributes used as input for the ML algorithm. The differences obtained for farmers' expertise ranged between $24.5 \%$ for the whole training and $25.4 \%$ for more reduced training set (6 attributes). The differences obtained for CMT performance ranged between 22.5 and 22.9. The ML system respectively assessed suspect or CMT-positive 1,518 and 1,222 records respectively while the training set included 2,293 and 1,780 records in these categories. Consequently, the system did not consider $10.6 \%$ and $7.7 \%$ of the available records to be suspect or CMT-positive. However, the system considered any record of 818 cows as suspect according to farmers' expertise and 672 as CMTpositive, while the training set includes only 684 and 544 suspect or positive cows, respectively. Table 4 shows how the ML algorithm tended to classify records showing higher SCCs than the actual assessments as suspect or CMT-positive. However, the percentages of cows classified as healthy or CMT-negative were virtually the same irrespective of the actual classification or that of the system.

Table 3

Differences in classification (in percentage) between farmers' expertise (healthy or suspect) or CMT performance (positive or negative) and learning system (C4.5) performance obtained by cross validation of 10 folders repeated 5 times over the training set described in the text (Unterschiede in der Bewertung (in \%) zwischen der Sachkenntnis des Milchbauern (gesund oder verdächtig) oder den CMT-Ergebnissen (positiv oder negativ) und den Ergebnissen des AI-Lernsystems (C4.5), erhalten durch Cross-Validierung von 10 Ordnern, mit fünfmaliger Wiederholung am im Text beschriebenen Übungssatz)

\begin{tabular}{|c|c|c|}
\hline $\begin{array}{l}\text { Number of attributes } \\
\text { used }\end{array}$ & $\begin{array}{c}\text { C4.5 } \\
\text { differences }\end{array}$ & Description of attributes used \\
\hline \multicolumn{3}{|l|}{ Farmers’ expertise } \\
\hline 39 & 24.5 & All the attributes of the training set \\
\hline $11^{*}$ & 25.1 & $\begin{array}{l}\text { Previous individual linear score, individual SCC, dry cow } \\
\text { management, premilking teat sanitation, forestripping check, actual } \\
\text { linear score, number of lactation, herd size, lactating cows per } \\
\text { milker, milk urea concentration, number of clusters per milker }\end{array}$ \\
\hline $6^{* *}$ & 25.4 & $\begin{array}{l}\text { Actual linear score, number of lactation, herd size, lactating cows per } \\
\text { milker, milk urea concentration, number of clusters per milker }\end{array}$ \\
\hline \multicolumn{3}{|l|}{ CMT performance } \\
\hline 39 & 22.5 & All the attributes of the training set \\
\hline $14^{*}$ & 22.9 & $\begin{array}{l}\text { Number of milkers per farm, individual fat percentage, month of } \\
\text { lactation, individual milk yield, number of clusters per milker, } \\
\text { previous farm average milk yield, farm average milk yield, farm } \\
\text { average linear score, number of lactation, previous individual linear } \\
\text { score, herd size, lactating cows per milker, Actual linear score, } \\
\text { individual SCC }\end{array}$ \\
\hline $5^{* *}$ & 22.9 & $\begin{array}{l}\text { Previous individual linear score, herd size, lactating cows per milker, } \\
\text { present linear score, individual SCC }\end{array}$ \\
\hline
\end{tabular}

The ML system used here obtained similar results using 11 or 6 attributes (after a smooth or a hard screening respectively) to classify a cow as suspected of being non-healthy to those obtained using the full training set. Learning how to identify cows that are CMTpositive, the system used 15 and 5 attributes respectively. The linear score (actual or previous), lactation number, herd size, lactating cows per milker, milk urea concentration, number of clusters per milker and actual SCC were the most informative attributes for mimicking both farmers' expertise or CMT performance in dairy herds. 


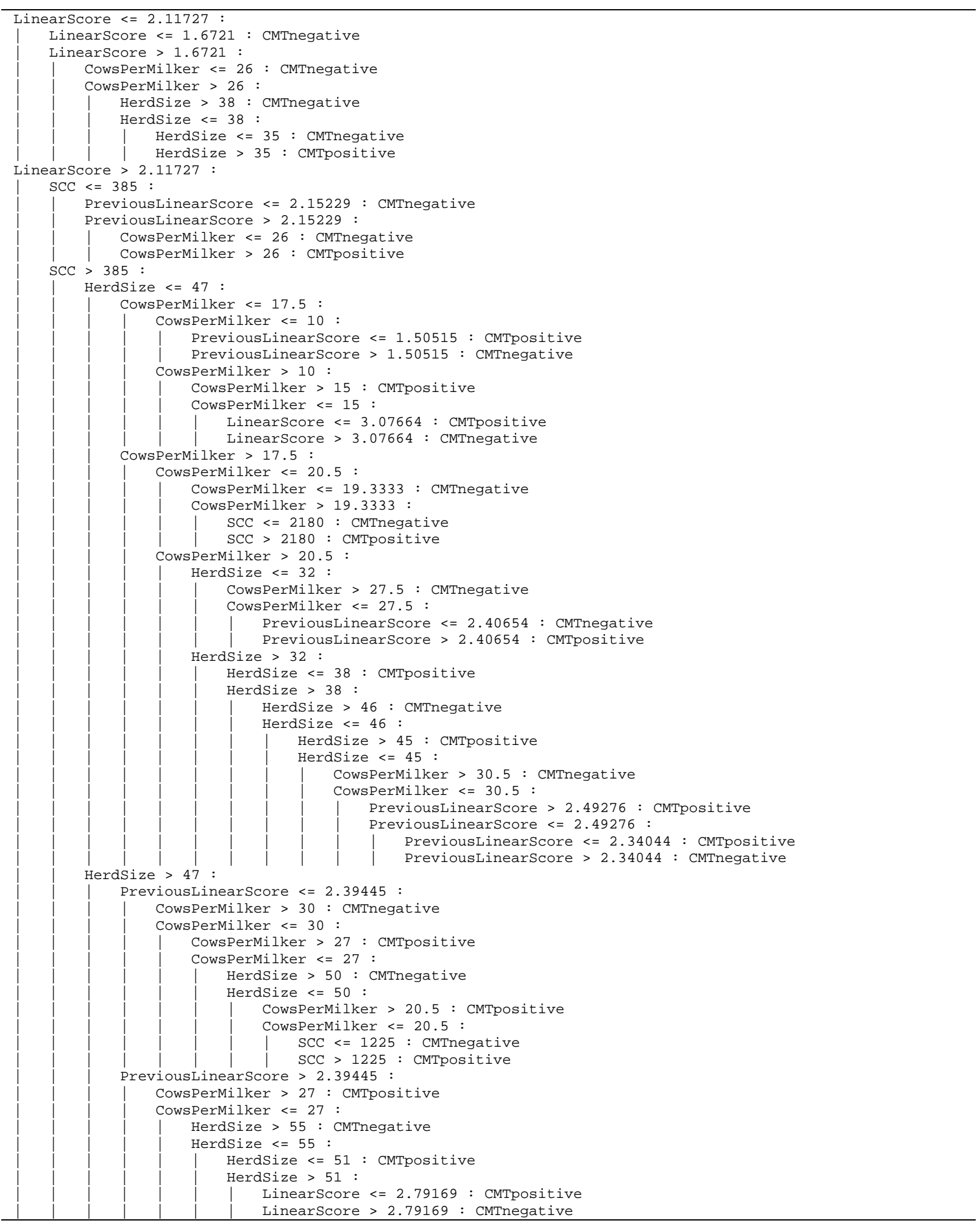

Fig. 2: Simplified decision tree to predict CMT performance (CMTpositive or CMTnegative) obtained by means of C4.5 using as input the following five attributes: previous individual linear score (LinearScore), herd size (HerdSize), lactating cows per milker (CowsPerMilker), present linear score (LinearScore) and individual Somatic Cell Count (SCC) (Vereinfachter Entscheidungsbaum zur Vorhersage der CMT-Ergebnisse (CMTpositiv oder CMTnegativ) ermittelt durch C4.5, mit der Eingabe folgender fünf Merkmale: vorheriges, individuelles lineares Ergebnis (LinearScore), Herdengröße(HerdSize), produzierende Kühe je Melkmaschine (CowsPerMilker), gegenwärtiges lineares Ergebnis (LinearScore) und individuelle Zählung somatischer Zellen (SCC))

However, when smooth screening of attributes is considered, the system presents 
substantial differences with respect to learning how to identify suspect or CMT-positive cows. In order to identify cows suspected of being non healthy, the ML system takes into account a number of management and milking routines (dry cow management, premilking teat sanitation and forestripping check), whereas in order to classify a record as CMT-positive, it basically takes production information of the cow and its herd from dairy recording. Farmers' expertise focused on identifying non-healthy animals by taking account of two main sources of information from a given cow: its age and the characteristics of its milk (SCC as linear score); the other information comes from the cow's environment, mainly the possible attention that milkers can offer to the cows, characterised as the number of lactating cows in a given month, the ratio cows/milker and the number of clusters per milker. Milk urea concentration can reflect a potential stress of the cow due to feeding imbalance (RICHARD et al., 2001).

\section{Table 4}

Percentage of records classified as suspect according to farmers' expertise or CMT-positive and the respective classifications obtained by the ML procedure (below) according to the actual SCC (less than 200,000 cells/ml, between 200,000 and 300,000 cells/ml and more than 300.000 cells/ml) (Anteil der als verdächtig eingestuften Eintragungen entsprechend der Sachkenntnis des Milchbauern oder positiven CMT-Ergebnissen und der jeweiligen Einstufung durch das AI-Verfahren (unten) nach der Zählung somatischer Zellen (weniger als 200000 Zellen/ml, zwischen 200000 und 300000 Zellen/ml und über 30.000 Zellen/ml))

\begin{tabular}{ccc}
\hline Actual SCC & Farmers' expertise & CMT \\
\hline less than 200,000 cells/ml & 54.4 & 49.6 \\
between 200,000 and 300,000 cells/ml & 34.5 & 38.9 \\
& & 11.2 \\
more than 300.000 cells/ml & 10.3 & 8.5 \\
& 35.3 & 39.2 \\
\hline
\end{tabular}

\section{Discussion}

The information obtained from the questionnaire survey highlights the fact that the management conditions of the dairies were quite homogeneous across herds (Tables 1 and 2). Most large farms had a loose housing system, while most small farms had a tied housing system. In spite of the farm size, the most frequent bedding system was rubber or concrete, and almost $95 \%$ of the dairies used some type of bedding sanitation. The number of milkers per farm was more dependent on the availability of family members than on herd size. Most herds seemed to follow sound mastitis control procedures: $70 \%$ milked the cows with a proper sequence; almost $85 \%$ checked the milk before milking used paper towels to dry teats and applied some kind of system to disinfect teats before milking, and virtually all of the farms sanitised teats after milking. To dry the cows, an abrupt cessation of milking was preferred, and $95 \%$ of the farms administered some kind of therapy to dry cows.

Human expertise and CMT performance are expected to present substantial errors. However, the performance of our system is consistent with others obtained from literature. Yang et al. (2000) using test-day records and conformation traits information to predict clinical mastitis obtained an overall efficiency of the predicting ability of their Artificial Neural Network (ANN) based system of 76.2\%; in other words, it has an average error of $23.8 \%$ which is similar to the errors reported in Table 3 . The probabilities of diagnosing the mastitis bacteriological status of dairy herds by means of 
ANNs and using test-day records and information of management practices ranged from 57 to $71 \%$ in a study by HEALD et al. (2000).

To learn how to mimic CMT performance, the system characterises the environment of a given cow in a different way than when mimicking farmers' expertise. The productive performance of a given cow in a given herd seems to be sufficient to predict CMTpositiveness accurately. These factors can characterise the possible stress affecting the cow leading to an increase in the incidence of mastitis (GIESECKE, 1985). The system clearly uses both SCC and linear score information to predict CMT results and, to a lesser degree, to mimic farmers' expertise. SCC and its log-linear transformation seem to provide different information. Probably, the linear score shows a linear relationship with other factors affected by subclinical mastitis only within a given range of SCC (HORTET and SEEGERS, 1998). ML procedures can take into account different sources of information regardless of their non-linear relationships (GOYACHE et al., 2001).

Although decision rules obtained from the available training set should be tested in different productive conditions, the techniques presented in this paper can be generalised. Dairy recording organisations usually provide farmers useful information to identify animals expected to produce persistently high SCCs. This information is often based on the definition of a SCC threshold above which a given animal is highlighted as possibly being subclinical mastitic. ML-based systems fall outside these considerations because their assessments are obtained taking into account the individual profile of a given dairy in given production conditions.

\section{Conclusions}

We conclude that ML techniques can be used by dairy organisations to give recommendations to restrain SCC based on the particular production conditions of a given farm. A scenario in which robot milking can gradually replace conventional milking will require a different concept of herd management referring specially to the possibilities of computerised monitoring, analysis and control of individual animals in a transparent manner to the user (SPAHR and MALTZ, 1997). The implementation of knowledge-based tools will deal with this task.

\section{Acknowledgements}

This paper was partially funded by a grant from CICYT-FEDER, No. 1FD97-0995-C0303. The authors would like to thank Asturiana de Control Lechero S. Coop. (ASCOL; http://www.viaganadera.com/ascol/) and Corporación Agroalimentaria Peñasanta S.A. (CAPSA) for their invaluable help and cooperation.

\section{References}

ALLORE, H.G.; JONES, L.R.; MERRILL, W.G.; OLTENACU, P.A.:

A decision support system evaluating mastitis information. J. Dairy Sci. 78 (1995), 4382-1398

BALTAY, Z.:

Hygienic quality of cow bulk tank mil depending on the method of udder preparation for milking. Arch.

Tierz., Dummerstorf 46 (2003), 405-411

DEL COZ, J. J.; LUACES, O.; QUEVEDO, J.R.; ALONSO, J.; RANILLA, J.; BAHAMONDE, A.:.

Self-Organizing Cases to Find Paradigms. Lect. Notes Comput. Sci. 1606 (1999), 527-536

GIESECKE W.H.:

The effect of stress on udder health of dairy cows. Onderstepoort J. Vet. Res. 52 (1985), 175-193

GOYACHE, F.; BAHAMONDE, A. ALONSO, J.; LÓPEZ, S.; ALONSO, J.; DEL COZ, J.J.; QUEVEDO, J.R.;

RANILLA, J.; LUACES, O.; ALVAREZ, I.; ROYO, L.; DÍEZ, J.: 
The usefulness of Artificial Intelligence techniques to assess subjective quality of products in the food industry. Trends in Food Science \& Technology 12 (2001), 370-381

DÍEZ, J.; BAHAMONDE, A.; ALONSO, J.; LÓPEZ, S.; DEL COZ, J.J.; QUEVEDO, J.R.; RANILLA, J.; LUACES, O.; ÁLVAREZ, I.; FERNÁNDEZ, I.; ROYO, L.J.; GOYACHE, F.:

Artificial Intelligence techniques point out differences in classification performance between light and standard bovine carcasses. Meat Sci. 64 (2003), 249-258

HEALD, C.W.; KIM, T.; SISCHO, W.M.; COOPER, J.B.; WOLFGANG, D.R.:

A computerised mastitis decision aid using farm-based records: an artificial neural network approach. J. Dairy Sci. 83 (2000), 711-720

HOGEVEEN, H.; VARNER, M.A.; BRÉE, D.S.; DILL, D.E.; NOORDUHIZEN-STASSEN, E.N.; BRAND, A.: Development of an integrated knowledge-based system for management support on dairy farms. J. Dairy Sci. 77 (1994), 3704-3715

HORTET, P.; SEEGERS, H.:

Calculated milk production losses associated with elevated somatic cell counts in dairy cows: review and critical discussion, Vet. Res. 29 (1998), 497-510

KHAITSA, M.L.; WITTUM, T.E.; SMITH, K.L.; HENDERSON, J.L.; HOBLET, K.H.:

Herd characteristics and management practices associated with bulk-tank somatic cell counts in herds in official Dairy Herd Improvement Association programs in Ohio. Am. J. Vet. Res. 61 (2000), 1092-1098

MILLER, G. Y.; EASTRIDGE, M. L.; HUESTON, W. D.; HOBLET, K. H.:

Use of Dairy Herd Improvement somatic cell information by Ohio dairy producers and their perceptions of mastitis. J. Dairy Sci. 71 (1988), 2284

NATZKE, R.P.:

Detection of mastitis. In: Wilcox, D.J. et al. (Eds.), Laroe dairy herd management, University of Florida, Gainesville, USA, pp. 537-546, 1978

QUEVEDO, J. R.; DEL COZ, J. J.; DÍEZ, J.:

Filtrando atributos para mejorar el aprendizaje automático. In: Bahamonde, A.; Pérez Otero, R. (Eds.), Actas CAEPIA 1. Servicio de Publicaciones de la Universidad de Oviedo (2001).

QUINLAN, J.R. (Ed.):

C4.5: Programs for Machine Learning, San Mateo, CA: Morgan Kaufmann, (1993).

RICHARD, W.; JEROCH, H.; SPILKE, J.:

Fütterungs- und nicht fütterungsbedingte Einflüsse auf den Milchharnstoffgehalt von Milchkühen. I. Mitt.: Fütterungsbedingte Einflussfaktoren auf den Milchharnstoffgehalt von Milchkühen. Arch. Tierz., Dummerstorf 44 (2001), 251-262

SAS INSTITUTE INC.:

SAS user's guide: Statisticsed SAS Institute, Inc, Cary, NC, USA (1999)

SKRZARD, R.; WOJTOWSKI, J.; FAHR, R.-D.;

Hygienic quality of cow bulk tank milk depending on the method of udder preparation for milking. Arch. Tierz., Dummerstorf 45 (2002), 349-357

SPAHR, S.L.; MALTZ, E.:

Herd management for robot milking. Comput. Electron. Agric. 17 (1997), 53-62

YANG, X.Z.; LACROIX, R.; WADE, K.M.:

Investigation into the production and conformation traits associated with clinical mastitis using artificial neural networks. Can. J. Anim. Sci. 80 (2000), 415-426

Received: 2004-06-03

Accepted: 2005-02-16

Corresponding Author

FELIX GOYACHE, PhD

SERIDA-Somió

Área de Genética y reproducción Animal

C/ Camino de los Claveles 604,

E-33203 Gijón (Asturias), Spain

E-Mail: fgoyache@serida.org 